\title{
DRIMYS BRASILIENSIS ESSENTIAL OIL AS A SOURCE OF DRIMENOL
}

\author{
L. M. ZEM ${ }^{1 *}$, K. C. ZUFFELLATO-RIBAS ${ }^{1}$, M. I. RADOMSKI ${ }^{2}$, H. S. KOEHLER ${ }^{1}$ and C. DESCHAMPS ${ }^{1}$ \\ ${ }^{1}$ Universidade Federal do Paraná \\ ${ }^{2}$ Embrapa Florestas \\ luzem@uol.com.br
}

Article submitted in February/2016 and accepted in March/2016

DOI: $10.15628 /$ holos.2016.3192

\section{ABSTRACT}

Drimys brasiliensis Miers is a native plant species to the Atlantic Forest, commonly known as cataia, and used as a stimulant, anti-diahrreal, antipyretic, among other properties. Dried and fresh leaves of cataia were collected in autumn/2012, submitted to hydrodistillation in a Clevenger graduated apparatus over a period of 4 hours after reaching the boiling point, then essential oil was collected. In oil from green leaves, 49 compounds were identified, being $65.0 \%$ sesquiterpenes, $12.0 \%$ monoterpenes and $23.0 \%$ other substances. In oil from dry leaves, 40 compounds were identified, being $76.1 \%$ sesquiterpenes, $2.0 \%$ monoterpenes and $21.9 \%$ other
\end{abstract}

compounds. The main constituents in green leaves were germacrene D (8.9\%), bicyclegermacrene (5.3\%), epialpha-cadinol (5.1\%), alpha-cadinol (6.0\%), and drimenol (9.3\%). In dry leaves the main constituents were germacrene $D(6.3 \%),(E)$-nerodidol (5.4\%), spathulenol (9.5\%), epi-alpha-cadinol (5.5\%), alpha-cadinol (6.7\%), and drimenol (11.6\%). Due to its composition, the species may possibly present some biological activities like antifungical, antibacterial, insectifuge, molluscicide, and also the pharmacological properties that the species may present.

KEYWORDS: Cataia, Sesquiterpene, Monoterpene, Composition.

\section{ÓLEO ESSENCIAL DE DRIMYS BRASILIENSIS COMO FONTE DE DRIMENOL}

\section{RESUMO}

Drimys brasiliensis Miers é uma espécie nativa da Mata Atlântica, conhecida popularmente por cataia, utilizada como estimulante, antidiarreica, antifebril, dentre outras propriedades. Folhas frescas e secas de cataia foram coletadas no outono/2012, submetidas à hidrodestilação em aparelho graduado tipo Clevenger durante um período de 4 horas após ebulição, retirando-se em seguida o óleo. No óleo de folhas frescas foram identificados 49 compostos, sendo 65,0\% sesquiterpenos, $12,0 \%$ monoterpenos e $23,0 \%$ de outras substâncias. Já no óleo de folhas secas identificou-se 40 compostos, sendo $76,1 \%$ sesquiterpenos, $2,0 \%$ monoterpenos e $21,9 \%$ de outros compostos. Os principais constituintes para as folhas frescas foram germacreno $D(8,9 \%)$, biciclogermacreno $(5,3 \%)$, epi-alfacadinol $(5,1 \%)$, alfa-cadinol $(6,0 \%)$ e drimenol $(9,3 \%)$. Já para as folhas secas, os principais constituintes foram germacreno D $(6,3 \%)$, (E)-nerodidol $(5,4 \%)$, espatulenol (9,5\%), epi-alfa-cadinol (5,5\%), alfa-cadinol $(6,7 \%)$ e drimenol (11,6\%). Devido a sua composição, a espécie possivelmente pode possuir algumas atividades como antifúngicas, antibacterianas, além de insetífuga, moluscocida e com propriedades farmacológicas que a espécie pode possuir.

PALAVRAS-CHAVE: Cataia, Sesquiterpeno, Monoterpeno, Composição. 


\section{INTRODUCTION}

Commonly known as "cataia", Drimys brasiliensis is a species native that can be used for stimulant to the popular medicine because of the oil composition. Ribeiro et al. (2008) found that the essential oils found in the leaves was lethal to cattle ticks and canines.

Drimys stands out for display by several pharmacological effects secondary metabolites responsible scientifically proven, including anti-inflammatory activities, antibacterial, antifungal, cytotoxic, molluscicide piscicide and regulating plant growth. Among the major classes of substances found are the sesquiterpenes drimanos, flavonoids and aromadendranos (MORTON, 1981; SIMÕES et al., 1986; JANSEN; GROOT, 1991; ANDRÉ et al., 1999).

Thus, according to Gomes et al. (2013), the chemical study of the essential oil Drimys brasiliensis allows to know their biological activities and evaluate their toxicity, to find out more about its therapeutic potential and its possible adverse effects, thus increasing safety its use by the population.

There are several studies on the essential oil chemical composition of Drimys brasiliensis bark; however, according to Radomski et al. (2013), there is some difficulty in this study because it is not possible to collect on a large scale or at different times of the year in the same plant as the depletion of the bark on the stem of the same would result in impairment of the phloem sap flow, which the long-term, culminating with the death of the plant.

In order to study alternative for essential oil extraction recommendation Drimys brasiliensis, this study aimed to characterize the essential oil of fresh and dried leaves of this species and analyze your components.

\section{LITERATURE REVIEW}

Commonly known as "cataia" or "casca-de-anta", Drimys brasiliensis is a species native to the Atlantic Forest Biome, occurring in the Brazilian states of Bahia, Minas Gerais, Espirito Santo, Rio de Janeiro, São Paulo, Paraná, Santa Catarina and Rio Grande do Sul (TRINTA \& SANTOS, 1997).

In popular tradition is a medicine of internal use, known as a stimulant, antispasmodic, antidiahrreal, antipyretic and antibacterial (ALMEIDA, 1993), due to the presence of flavonoids and terpenoids in its composition (WITAICENIS et al., 2007).

The term essential oil is used to describe volatile oily liquids with strong and in most cases pleasant aroma, extracted mainly from plants. It is believed that, during their development, plants synthesize essential terpenoids for their own growth and development (UGAZ, 1994; ARAUJO et al., 2001).

According to Cruz (2013), various authors reported quite common presence of drimanic sesquiterpenes in essential oils of this species, like drimanial, drimenol, valdivilolide, polygodial, 1$\mathrm{b}$-( $p$-methoxycinnamoyl) polygodial and 1-b-( $p$-coumaroyloxy) polygodial.

Drimenol is a very important representative of drimanic sesquiterpenoids. This terpenol served as a starting compound in the synthesis of various natural drimanes (JANSEN \& GROOT, 1991; 
VLAD, 2006). According to Jansen \& Groot (1991), drimenol has the plant growth regulatory activity comparable with that of heteroauxin.

The importance of drimenol as a starting compound for the synthesis of drimanic compounds, on one hand, and the fact that its contents in natural sources is relatively low, on the other hand, have stimulated studies of its synthesis (JANSEN \& GROOT, 1991).

Therefore, this work had the objective to characterize the essential oil extracted from fresh and dried leaves of Drimys brasiliensis.

\section{MATERIAL AND METHOD}

Leaves of 5 years old Drimys brasiliensis Miers, commonly known as "cataia", Winteraceae family, plants were used for the essential oil extraction. The plant material was obtained from plants grown at Embrapa Florestas, situated at south latitude 25019'16" and west longitude 49009'31". According to the Köppen classification, climate of the region is Cfb type, with average temperature of the hottest month above $10{ }^{\circ} \mathrm{C}$, mild summers and winters with frequent icings, with tendency to rainfall concentrations during summer, however without a defined dry season. Dried samples of the species where stocked in the Embrapa Florestas herbarium with the HFC classification $n^{\circ} 7963$, who was collected in Colombo (PR) by W. Mashio in January, 2005.

Extraction of the essential oil of Drimys brasiliensis was performed in the Plant Ecophysiology Laboratory of the Department of Phytotechnology and Phytosanitary Sciences of the Federal University of Parana (Universidade Federal do Paraná - UFPR), from leaves collected in autumn/2012.

The experiment was conducted using dried and fresh leaves, randomly collected from stock plants, lately submitted to hydrodistillation in a Clevenger type graduated apparatus (WASICKY, 1963), over a period of 4 hours after reaching the boiling point.

To extract the essential oil from dry leaves, the green material was left in an oven at $45^{\circ} \mathrm{C}$ over a period of 7 days, to obtain the needed dried material.

Essential oil was processed in a centrifuge for 2 minutes at $100 \mathrm{rpm}$. Essential oil samples were quantified and stocked at $-20^{\circ} \mathrm{C}$, until the moment of the chromatographic analysis.

Quantification of the essential oil was performed using precision micropipettes (100-1000 $\mu \mathrm{L}$ ). Samples of $30 \mu \mathrm{L}$ taken from the total extracted oil were weighted and their weight was divided by the $30 \mu \mathrm{L}$ volume, thus obtaining the density of the essential oil (L). Total weight of the sample was then divided by this density to obtain the total volume in $\mathrm{g} \mathrm{L}^{-1}$.

The essential oil samples were analyzed by gas chromatography coupled to mass spectrometry (GC / MS). The equipment was Varian gas chromatograph, Model CP 3800 with FID detector (CG_FID) capillary column Chrompack fused silica CP-SIL 8 CB, $0.25 \mathrm{~mm}$ internal diameter, $30 \mathrm{~m}$ long and $0.25 \mathrm{uM}$ liquid film. Injector temperature: $250^{\circ} \mathrm{C}$, split 1:300, injected sample volume: 1.0uL . Carrier gas: helium $1 \mathrm{~mL} / \mathrm{min}$ constante. Gás makeup: synthetic air, nitrogen and hidrogênio. Temperatura FID detector: $300^{\circ} \mathrm{C}$. Oven Temperature Program: initial $50^{\circ} \mathrm{C}$ temperature rise to 180 ${ }^{\circ} \mathrm{C}$ at a rate of $10^{\circ} \mathrm{C}$ lasting for 20 minutes; temperature rise to $200{ }^{\circ} \mathrm{C}$ at a rate of $20^{\circ} \mathrm{C}$ for 1 minute 
remains. Total run time: 35-40 minutes. Chemical characterization of the essential oil of Drimys brasiliensis was performed by Embrapa Agroindustria de Alimentos, located in Rio de Janeiro (RJ).

\section{RESULT AND DISCUSSION}

The essential oil yield from fresh leaves was $0.0236 \mu \mathrm{L} / \mathrm{g}$ of dry mass and yield from dried leaves was $0.0221 \mu \mathrm{L} / \mathrm{g}$. The chemical composition of essential oil from dried and green leaves of Drimys brasiliensis is presented in Table 1.

In the oil of fresh and dried leaves, 49 and 40 compounds where respectively identified, with predominance of sesquiterpenes that were $65 \%$ in green leaves and $76.1 \%$ in dry leaves. Similar results were obtained by Limberger et al. (2007) in essential oil samples from fresh and dried leaves of Drymis brasiliensis in Rio Grande do Sul State, being 37.1\% from fresh leaves and $65.4 \%$ from dried leaves. Lago et al. (2010) also reported predominance of sesquiterpenes equal to $57.31 \%$ in the oil from leaves of this species, collected in Campos do Jordão (SP).

In this study, polygodial sesquiterpene was not detected, although it is common in some studies with essential oils of Drimys brasiliensis (MUÑOZ-CONCHA et al., 2004). The sesquiterpene drimenol was the most abundant compound found in this study with $9.3 \%$ in the fresh and $11.6 \%$ in the dried material (Table 1).

According to Costa et al. (2005), the chemical composition and yield of essential oil is influenced by the plants drying process. The fact that percentage of drimenol increased in the composition of essential oil extracted from dry leaves may depend on the drying process. This process is intended to minimize loss of active principles and slow down their deterioration, and a very fast drying process could cause degradation. However, a very slow process could cause the establishment of undesirable microorganisms and, with water reduction, the quantity of active principles also increases (VON HERTWIG, 1991; SILVA \& CASALI, 2000).

Besides the sesquiterpenes, monoterpenes were also found in fresh and dried leaves of Drymis brasiliensis, and the highest amount were found in the essential oil from fresh leaves (12\%), when compared to dried leaves (2\%) (Table 1 ).

One of the factors justifying the difference in the chemical composition of fresh and dried leaves oil is the fact that they have little stability, especially in the presence of air, light and heat (SIMÕES \& SPITZER, 2004). Thus, it is argued that the temperature for drying the leaves influenced the chemical composition of essential oils when compared with the oil of fresh leaves .

Compounds with relative quantity $>5 \%$ in the essential oil of fresh material were germacrene D (8.9\%), bicyclogermacrene (5.3\%), epi-alpha-cadinol (5.5\%), alpha-cadinol (6.0\%) and drimenol (9.3\%). For dry material the most represented compounds were germacrene $D(6.3 \%)$, (E)-nerolidol (5.4\%), spathulenol (9.5\%), epi-alpha-cadinol (5.5\%), alpha-cadinol (6.7\%) and drimenol (11.6\%) (Table 1). 
TABLE 1: Compounds of the essential oil from green and dried leaves of Drimys brasiliensis.

\begin{tabular}{|c|c|c|}
\hline Identification of the compound & $\begin{array}{l}\text { Quantity in the Essential Oil from } \\
\text { green material }\end{array}$ & $\begin{array}{c}\text { Quantity in the Essential Oil from } \\
\text { dried material }\end{array}$ \\
\hline Alpha-pinene & 1,5 & 0,3 \\
\hline Sabinene & 1,0 & - \\
\hline Beta-pinene & 2,2 & 0,5 \\
\hline Myrcene & 0,3 & - \\
\hline Alpha-terpinene & 0,5 & - \\
\hline Beta-phalandrene & 3,3 & 0,5 \\
\hline Gamma-terpinene & 1,0 & - \\
\hline Terpinolene & 0,5 & - \\
\hline 4-terpineol & 1,5 & 0,7 \\
\hline Safrol & 1,1 & - \\
\hline Alpha-cubebene & 0,4 & 0,4 \\
\hline Beta-borbuonene & 1,1 & 1,1 \\
\hline Beta-elemene & 0,8 & 1,0 \\
\hline (E)-caryophyllene & 1,0 & 1,1 \\
\hline Beta-copaene & 0,5 & 0,5 \\
\hline Alpha-humulene & 0,6 & 1,0 \\
\hline Gamma-muurolene & 0,6 & 0,7 \\
\hline Germacrene D & 8,9 & 6,3 \\
\hline Bicyclogermacrene & 5,3 & 3,9 \\
\hline Alpha-Muurolene & 0,5 & - \\
\hline Gamma-cadinene & 0,7 & 0,8 \\
\hline Delta-cadinene & 2,4 & 2,9 \\
\hline (E)-nerodidol & 4,3 & 5,4 \\
\hline Spathulenol & 3,8 & 9,5 \\
\hline Globulol & 3,1 & 3,6 \\
\hline Viridiflorol & 1,4 & 2,6 \\
\hline Rosifoliol & 1,1 & 1,2 \\
\hline Junenol & 1,0 & 1,1 \\
\hline n.i. & 0,8 & 0,8 \\
\hline Epi-cubenol & 2,4 & 2,4 \\
\hline Isospathulenol & 1,3 & 2,0 \\
\hline Epi-alpha-cadinol & 5,1 & 5,5 \\
\hline Alpha-Muurolol & 1,6 & 2,0 \\
\hline Alpha-cadinol & 6,0 & 6,7 \\
\hline Germacra-4(15),5,10(14)-trien-1?-ol & 1,0 & 2,0 \\
\hline drimenol & 9,3 & 11,6 \\
\hline ent-Rosa-5,15-diene & 2,9 & 0,9 \\
\hline Drimenine & 0,7 & 0,8 \\
\hline Kaurene & 0,9 & 0,9 \\
\hline Total (\%) & 100,0 & 100,0 \\
\hline Monoterpenes & 12,0 & 2,0 \\
\hline Sesquiterpenes & 65,0 & 76,1 \\
\hline Others & 23,0 & 21,9 \\
\hline
\end{tabular}

Santos et al. (2013) collected leaves of Drymis brasiliensis in the São Paulo State and detected variations in the following compounds when compared to this work: $9.5 \%$ sabinene, $10.5 \%$ myrcene, 10.6\% limonene and $28.3 \%$ cyclocolorenone. Gomes et al. (2013) identified $96.6 \%$ compounds in essential oil samples of Drimys brasiliensis. The main constituent was cyclocolorenone (18.3\%), followed by terpinen-4-ol (8.4\%) and myristicin (6.6\%). Finally, Lago et al. (2010), extracted essential 
oil from leaves of Drymis brasiliensis collected in the Umauarama district, in the municipality of Campos do Jordão (SP) and identified sixteen volatile compounds, with predominance of sesquiterpenes $(52.31 \%)$, being the main derivatives the cedrene $(6.87 \%)$, bicyclogermacrene (5.31\%), t-muurolol (7.75\%) and drimenol (9.96\%).

Those chemical differences found in the essential oil samples of this study, when compared to literature, may be due to the specific climatic conditions and to geographic conditions where plants had developed.

According to Kutchan (2001), secondary metabolites represent a chemical interface between plants and environment; thus, their synthesis is frequently influenced by environmental conditions. Roca-Pérez (2004), studying essential oil from leaves of Digitalis obscura, found lower cardenolides concentrations, like lanatoside $A$, in spring and with a rapid accumulation phase in summer followed by decrease in autumn. Wallaart et al. (2000) observed that metabolic stress caused by icing in Artemisia annua originated a $60 \%$ increase in artemisinin levels, coincident wih decrease of its biosynthetic precursor, the dihydroartemisinic acid.

According to Gobbo-Neto \& Lopes (2007), production of essential oils of Drymis brasiliensis, such as production of others secondary metabolites, is strongly influenced by environmental factors.

The presence of the sesquiterpene drimenol is very strong in the essential oil composition of the species (9.3\% and $11.6 \%$ respectively in green and dry leaves). This class of sesquiterpenes appears in a restricted group of angiosperms, like Winteraceae, Solanaceae, Canellaceae, Taxaceae and Polygonaceae, and has been raising particular interest due to the wide range of biological activities and sensory properties (ASAKAWA, 2004).

Sesquiterpenes with drimane structure may present biological activities like: antibacterial, antifungal, plant growth regulator, citotoxicity, mulloscicide, and others (JANSEN \& GROOT, 1991).

Due to this potential, drimenol have been used as a base material to obtain other more active natural drimanes or semi-synthetic derivatives with an increased biological activity (KUCHKOVA et al., 2009).

Another important application of drimenol is as precursor for ambrox and isoambrox, which are the most important synthetic substitutes of ambergris, nowadays one of the most valuable and one of the few materials with animal origin used in the perfumery industry (BENITES et al., 2006).

It is important to point out that some compounds identified in this work, like beta-elemene, (E)-caryophylene, alpha-humulene, gamma-muurolene, delta-cadinene, (E)-nerolidol, spathulenol, globulol, viridiflorol, rosifoliol, junenol, isospathulenol, epi-alpha-cadinol, alpha muurolol, alphacadinol, germacra-4(15),5,10(14)-trien-1-alpha-ol and drimenol, after drying of leaves, increased their percentage in the essential oil composition. This demonstrates that drying leaves at $45{ }^{\circ} \mathrm{C}$ has qualitative influence on the extracted essential oil of Drymis brasiliensis.

According to Silva et al. (1999), losses of active principles in essential oil of dry leaves are due to degradation caused by metabolic processes, hydrolysis, light, enzymatic, oxidation, fermentation, heat and microbiologic contaminations. 


\section{CONCLUSIONS}

Under the conditions of the experiment that was conducted in this work it is possible to conclude that, for the composition of the essential oil of Drymis brasiliensis there was predominance of sesquiterpenes in the fresh material (65.0\%) and in the dried material (76.1\%). The main compounds of the green material were germacrene $D(8.9 \%)$, bicyclogermacrene (5.3\%), epi-alphacadinol (5.1\%), alpha-cadinol (6.0\%) and drimenol (9.3\%), while for the dry material were germacrene D (6.3\%), (E)-nerolidol (5.4\%), spathulenol (9.5\%), epi-alpha-cadinol (5.5\%), alphacadinol (6.7\%) and drimenol (11.6\%). Because of its composition, the species may possibly present some biological activities like antifungical, antibacterial, insectifuge, pharmacological and molluscicide.

\section{ACKNOWLEDGMENTS}

The authors would like to thank Embrapa Florestas and Universidade Federal do Paraná, for the support given throughout the development of this project.

\section{REFERENCES}

1. ALMEIDA, E.R. Plantas medicinais brasileiras, conhecimentos populares e científicos. São Paulo: Hemus, 1993. 341p.

2. ANDRE, E.; MALHEIROS, A.; CECHINEL-FILHO, V.; YUNES, R.A.; CALIXTO, J.B. Mechanisms underlying the relaxation caused by the sesquiterpene polygodial in vessels from rabbit and guinea-pig. European Journal Pharmacology, v.386, n.1, p.47-53, 1999.

3. ARAUJO, A.J., LORDELLO, A.L.L., SALES MAIA, B.H.L.N. Análise comparativa dos óleos essências de folhas e galhos de Ocotea puberula (LAURACEAE). Revisão Visão Acadêmica, v.2, n.2, p.8184, 2001.

4. ASAKAWA, Y. Chemosystematics of the Hepaticae. Phytochemistry, v.65, n.6, p.623-669, 2004.

5. BENITES, J., LOPES, J., FARIAS, J.G., CORTES, M. The preparation of oxygenated derivatives of ambrox and isoambrox from drimenol. Journal of the Chilean Chemical Society, v.51, n.3, p.979981, 2006.

6. COSTA, L.C.B., CORRÊA, R.M, CARDOSO, J.C.W., PINTO, J.E.B.P., BERTOLUCCI, S.K.V., FERRI, P.H. Secagem e fragmentação da matéria seca no rendimento e composição do óleo essencial de capim-limão. Horticultura Brasileira, v.23, n.4, p.956-959, 2005.

7. CRUZ, B.P. Comparação da anatomia foliar e dos óleos essenciais de Drimys brasiliensis Miers (Winteraceae) em uma floresta ombrófila densa altomontana. 87 f. Lavras, 2007. Dissertação de Mestrado em Botânica - Universidade Federal de Lavras, 2013.

8. GOBBO NETO, L., LOPES, N.P. Plantas medicinais: fatores de influência no conteúdo de metabólitos secundários. Química Nova, v.30, n.2, p.374-381, 2007.

9. GOMES, M.R.F., SCHUH, R.S., JACQUES, A.L.B., DORNELES, G.G., MONTANHA, J., ROEHE, P.M., BORDIGNON, S., DALLEGRAVE, E., LEAL, M.B., LIMBERGER, R.P. Biological assessment (antiviral and antioxidante) and acute toxicity of essencial oils from Drimys angustifolia and D. 
brasiliensis. Revista Brasileira Farmacognosia, v.23, n.2, p.284-290, 2013.

10. JANSEN, B.J.M., GROOT, A.D. The occurrence and biological activity of drimane sesquiterpenoids. Natural Product Reports, v.8, n.3, p.309-318, 1991.

11. KUCHKOVA, K.I., ARYCU, A.N., VLAD, P.F. Synthesis of 11-aminodrim-7-ene from drimenol. Chemistry of Natural Compounds, v.45, n.3, p.367-370, 2009.

12. KUTCHAN, T.M. Ecological arsenal and developmental dispatcher. The paradigm of secondary metabolism. Plant Physiology, v.125, n.1, p.58-60, 2001.

13. LAGO, J.H.G., CARVALHO, L.A.C., SILVA, F.S., TYAMA, D.O., FÁVERO, O.A., ROMOFFO, P. Chemical composition and anti-inflammatory evaluation of essential oils from leaves and stem barks from Drimys brasiliensis Miers (Winteraceae). Journal of the Brazilian Chemical Society, v.21, n.9, p.1760-1765, 2010.

14. LIMBERGER, R.P., SCOPEL, M., SOBRAL, M., HENRIQUES, A.T. Comparative analysis of volatiles from Drimys brasiliensis Miers and $D$. angustifolia Miers (Winteraceae) from Southern Brazil. Biochemical Systematics and Ecology, v.35, n.3, p.130-137, 2007.

15. MORTON, J.F. Winteraceae, Drimys Family. In.__. Thomas CC Atlas of medical plants in middle America-Bahamas to Yucatan. Ilinóis: Springfield Thomas, p.219, 1981.

16. MUÑOZ-COCHA, D., VOGEL, H., RAZMILIC, I. Variación de compuestos químicos em hojas de poblaciones de Drimys spp. (Magnoliophyta: Winteraceae) em Chile. Revista Chilena de História Natural, v.77, n.1, p.43-50, 2004.

17. RADOMSKI, M.I.; WEISER, A.H.; ZUFFELLATO-RIBAS, K.C.; FONSECA, K.R.; CARPANEZZI, A.A. Cataia (Drimys brasiliensis Miers). Colombo: Empresa Brasileira de Pesquisa Agropecuária Embrapa Florestas, 2013. Documentos.

18. ROCA-PÉREZ, L., BOLUDA, R., GAVIDIA, I., PÉREZ-BERMÚDEZ, P. Seasonal cardenolide production and Dop5betar gene expression. In natural population of Digitalis obscura. Phytochemistry, v.65, n.13, p.1869-1878, 2004.

19. SANTOS, T.G., DOGNINI, J., BEGNINI, I.M., REBELO, R.A., VERDI, M., GASPER, A.L., DALMARCO, E.M. Chemical caracterization os essential oils of Drimys angustifólia Miers (Winteraceae) and antibacterial activity of their major compounds. Journal of the Brazilian Chemical Society, v.24, n.1, p.164-170, 2013.

20. SILVA, F., CASALI, V.W.D. Plantas medicinais e aromáticas: Pós-colheita e óleos essenciais. 1. ed. Viçosa: Arte e Livros, 2000. 135p.

21. SILVA, F., CASALI, V.W.D., LIMA R.R., ANDRADE, N.J. Qualidade pós-colheita de Achillea millefolium L., Origanum vulgare L. e Ptroselinum crispum (Miller) A.W. Hill em três embalagens. Revista Brasileira de Plantas Medicinais, v.2, n.1, p.37-41, 1999.

22. SIMOES, C.M.O.; MENTZ, L.A.; SCHENKEL, E.P.; IRGANG, B.E.; STEHMANN, J.R. Plantas da medicina popular no Rio Grande do Sul. Porto Alegre: Editora da Universidade/UFRGS, 1986. $147 p$.

23. SIMÕES, C.M.O.; SPITZER, V. Óleos voláteis. In: - Farmacognosia: da planta ao medicamento. 5 ed. Porto Alegre/Florianópolis: UFRGS/UFSC, p.467-495, 2004.

24. TRINTA, E.F., SANTOS, E. Flora Ilustrada Catarinense. Itajaí: BR Petrobras, 1997. 19p. 
25. UGAZ, O.L. Investigación Fitoquímica: métodos en el estudio de Productos Naturales. Peru: Pontificia Universidad Católica del Perú, 1994. 281p.

26. VLAD, P.F. Studies in Natural Products Chemistry. In: Rahman, A. (Ed.). Bioactive Natural Products. Amsterdam: Elsevier, 2006, p.393-432.

27. VON HERTWING, I. F. Plantas aromáticas e medicinais: plantio colheita secagem comercialização. São Paulo: Icone, 1991. 414p.

28. WALLAART, T.E., PRAS, N., BEEKMAN, A. C., QUAX, W. J. Seasonal variation of artemisinin and its biosynthetic precursors in plants of Artemisia annua of different geographical origin: proof for the existence of chemotypes. Planta Medicinal, v.66, p.57- 62, 2000.

29. WASICK, R. Uma modificação do aparelho de Clevenger para extração de óleos essências. Revista da Faculdade de Farmácia e Bioquimíca, v.1, n.1, p.77-81, 1963.

30. WITAICENIS, A., ROLDÃO, E.F., SEITO, L.N., ROCHA, L.C., DI STASI, L.C. Pharmacological and Toxicological studies of Drimys angustifolia Miers. (Winteraceae). Journal Ethnophamacology, v.111, n.3, p.541-546, 2007. 